\title{
PERLINDUNGAN DAN PEMENUHAN HAK KORBAN TINDAK PIDANA DALAM SISTEM PERADILAN PIDANA
}

\author{
Nahdiya Sabrina \\ Fakultas Hukum Universitas Merdeka Malang \\ Jl. Terusan Raya Dieng 62-64 Malang \\ sabrina.nahdiya@unmer.ac.id
}

\begin{abstract}
The criminal justice system in Indonesia is now more concerned with criminal prosecution, so that the rights of victims of criminal offenses are often overlooked. This creates dissatisfaction in the self of criminal act. Because what the victim really wants is not only the punishment of the perpetrator, but also the return of the rights he should have before the crime. Through several laws and regulations, namely Law No. 31 of 2014 on the Amendment of Law No. 13 of 2006 on the Protection of Witnesses and Victims that became the main umbrella of the protection of victims of crime, as well as Law No. 23 of 2004 on the Elimination of Violence in the Household has actually been regulated regarding the protection and rights of victims of this crime. The Witness and Victim Protection Act explicitly places the state through LPSK as the main party providing protection for Witnesses and Victims. However there are articles in the Law which need further explanation because there are juridical issues of unclear norms that regulate, so there are difficulties when applied in factual cases.
\end{abstract}

Keywords: Victim Criminal Act, Right to Crime Victim, Criminal Court.

\begin{abstract}
ABSTRAK
Sistem peradilan pidana di Indonesia saat ini lebih mementingkan pemidanaan pada pelaku, sehingga hakhak korban tindak pidana sering tidak diperhatikan. Hal ini menimbulkan ketidak puasan tersendiri pada diri koban tindak pidana. Karena yang sesungguhnya diinginkan oleh korban tidak hanya penghukuman kepada pelaku, tetapi juga kembalinya hak-hak yang seharusnya ia miliki sebelum terjadinya kejahatan tersebut. Melalui beberapa peraturan perundang-undangan, yakni Undang-Undang Nomor 31 tahun 2014 tentang Perubahan atas Undang-Undang Nomor 13 tahun 2006 Tentang Perlindungan Saksi dan Korban yang menjadi payung utama perlindungan korban tindak pidana, juga Undang-Undang Nomor 23 tahun 2004 tentang Penghapusan Kekerasan dalam Rumah Tangga sebenarnya telah diatur mengenai perlindungan dan hak-hak korban tindak pidana ini. Undang-Undang Perlindungan Saksi dan Korban secara tersurat menempatkan negara, melalui LPSK sebagai pihak utama yang memberikan perlindungan terhadap Saksi dan Korban Namun terdapat pasal-pasal di dalam Undang-Undang tersebut yang perlu penjelasan lebih lanjut karena terdapat permasalahan yuridis berupa ketidak jelasan norma yang mengatur, sehingga terdapat kesulitan ketika di aplikasikan dalam kasus-kasus faktual.
\end{abstract}

Kata Kunci: Hak Korban Tindak Pidana, Korban Tindak Pidana, Peradilan Pidana. 
Sistem pemidanaan yang berlaku saat ini di Indonesia lebih menggunakan pendekatan penyelesaian perkara pidana dengan cara penghukumaan (pemidanaan) atau dikenal dengan istilah retributive justice. Semua bentuk kejahatan yang terbukti di persidangan diputus dengan cara menghukum pelaku, sedangkan hak-hak korban kejahatan seperti kurang diperhatikan.

Tergambar bahwa pendekatan retributive justice lebih focus pada pelaku dan mengenyampingkan hak-hak korban. Karena setiap penyelesaian perkara pidana dituntaskan dengan menghukum pelaku dengan tujuan menimbulkan efek jera dan membuat yang bersangkutan tidak kembali mengulangi perbuatannya (Abdul Haris Semendawai, Obssesionnews.com, 2017).

Kepentingan korban diwakili oleh negara melalui aparat penegak hukum dengan cara memidanakan pelaku, sedangkan korban hanya bisa menunggu dan menyaksikan apa yang dilakukan oleh negara. Terkadang, putusan hakim dapat memuaskan bagi korban, namun tidak jarang justru membuat korban kecewa, karena putusannya jauh dari rasa keadilan yang diidam-idamkan korban dan masyarakat (Abdul Haris Semendawai, Obssesionnews.com, 2017).

Contohlah misalnya seorang korban tindak pidana penggelapan, yang ia paling inginkan sebenarnya adalah kembalinya harta benda yang telah digelapkan oleh pelaku. Namun kenyataan yang banyak terjadi, sanksi pidana hanya sampai pada memidanakan pelaku. Namun hilangnya harta benda korban tindak pidana penggelapan ini tidak bisa dikembalikan, atau ia tetap menanggung kerugian atas perbuatan pelaku tersebut.

Korban utama atas terjadinya suatu tindak pidana bukanlah negara, sebagaimana dalam sistem peradilan pidana yang ada sekarang. Jadi hakhak korban seharusnya tetap diutamakan, yakni hak-haknya yang terampas akibat perbuatan pidana tersebut.
Sebenarnya paradigma restributive justice sudah mulai bergeser sejak diimplementasikannya paradigma retributive justice, yakni suatu pendekatan yang lebih menitikberatkan pada kondisi terciptanya keadilan dan keseimbangan bagi pelaku serta korbannya sendiri, ke beberapa peraturan perundangan, terutama yang berhubungan dengan korban tindak pidana adalah Undang-Undang Nomor 31 tahun 2014 tentang Perubahan atas Undang-Undang Nomor 13 tahun 2006 Tentang Perlindungan Saksi dan Korban. Undang-Undang ini telah diusung konsep baru dalam penggantian kerugian yang dialami oleh korban, yakni kompensasi dan restitusi.

Namun dalam Undang-Undang ini masih terdapat kekurangan yakni belum terakomodasinya hal-hal yang seharusnya sudah diatur. Tulisan ini mencoba menggali beberapa kekurangan yang terdapat dalam beberapa peraturan perundangan mengenai perlindungan dan pemenuhan hak korban suatu tindak pidana dan mencoba mencari gambaran baru perlindungan dan pemenuhan hak korban yang seharusnya sudah dimasukkan dalam peraturan perundang-undangan tersebut.

Uraian tersebut di atas, maka melahirkan beberapa rumusan masalah yang nantinya akan dikaji oleh penulis dalam tulisan ini antara lain adalah bagaimanakah pemenuhan hak dan perlindungan korban tindak pidana dalam sistem peradilan pidana di Indonesia saat ini dan apa permasalahan yang ada dalam peraturan perundang-undangan mengenai pemenuhan hak dan perlindungan korban tindak pidana.

\section{Korban dalam Sistem Peradilan Pidana Saat ini}

Konsep kejahatan dan siapa yang menjadi korban kejahatan adalah pangkal tolak untuk menjelaskan bagaimana posisi hukum korban. Ada 2 (dua) konsep kejahatan, pertama, kejahatan dipahami sebagai pelanggaran terhadap negara atau 
kepentingan publik yang dipresentasikan oleh instrumen demokratik negara. Kedua, kejahatan dipahami sebagai pelanggaran terhadap kepentingan orang perseorangan dan juga melanggar kepentingan masyarakat, negara, dan esensinya juga melanggar kepentingan pelakunya sendiri. Konsep yang pertama dilandasi oleh pemikiran yang berbasis pada konsep keadilan retributif, dan konsep yang kedua berlandaskan pada konsep keadilan restoratif (Mudzakkir, Tanpa Tahun, 25).

Pilihan orientasi sistem peradilan pidana pada gilirannya mengkondisikan praktik penyelesaian perkara pidana melalui sistem peradilan pidana ditandai dengan perhatian dan perlakuan yang berat sebelah yakni lebih banyak memberikan perhatian kepada pelaku tindak pidana (criminal, dader), tetapi mengabaikan korban tindak pidana (victim). Sebagaimana dikemukakan oleh Muladi, hal tersebut membawa konsekuensi logis, yaitu keadilan yang dihasilkan melalui proses peradilan pidana lebih merefleksikan kepentingan negara versus pelaku tindak pidana, namun tidak memperhatikan kepentingan dan rasa keadilan dari pihak korban tindak pidana (Natangsa Subakti, Tanpa Tahun, 3). Korban dalam lingkup viktimologi memiliki arti yang luas karena tidak hanya terbatas pada individu yang secara nyata menderita kerugian, tetapi juga kelompok, korporasi, swasta, maupun pemerintah, sedangkan yang dimaksud dengan akibat penimbulan korban adalah sikap atau tindakan korban dan atau pihak pelaku serta mereka yang secara langsung atau tidak terlibat dalam terjadinya suatu kejahatan.

Korban apabila merasakan hasil akhir dari penyelesaian perkara yang menimpanya tidak memenuhi rasa keadilan, maka yang tersisa adalah rasa kecewa, sakit hati, dan keinginan membalas dendam. Hal tersebut pada gilirannya menurunkan kemampuan kerja produktifnya sebagai warga masyarakat. Akumulasi dari rasa kecewa, sakit hati dan keinginan melakukan tindakan balas dendam bila ada kesempatan, merupakan sumber potensial terjadinya tindakan anarkhis dan tindak pidana baru, serta terjadinya disintegrasi sosial.

Pola kerja sistem peradilan pidana yang apatis terhadap kepentingan korban tindak pidana tidak bisa dilepaskan dari kebijakan legislatif di bidang hukum dan sistem peradilan pidana. Kebijakan legislatif di bidang hukum dan sistem peradilan pidana, jelas telah tertinggal jauh dibandingkan perkembangan yang terjadi di berbagai negara lain. Sistem peradilan pidana di berbagai negara lain telah beranjak lebih maju, perhatian tidak berhenti pada perbuatan yang dilarang dan pelaku tindak pidana, melainkan juga meliputi hak dan kepentingan korban tindak pidana (crime, offender, and victim oriented) (Natangsa Subakti, Tanpa Tahun, 3).

Pihak korban juga merasa diabaikan hakhaknya, antara lain dakwaan lemah, tuntutan ringan, tidak mengetahui perkembangan penanganan perkara, tidak menerima kompensasi, dan tidak terpenuhinya hak-hak yang lain (Bambang Waluyo, 2002 , 2). Sudah seharusnya kebijakan legislatif di bidang hukum dan sistem peradilan pidana di Indonesia beranjak maju dari yang selama ini berfokus pada perbuatan yang dilarang dan pelaku tindak pidana (crime and offender oriented), beralih pada orientasi perbuatan, tersangka dan korban.

Hadirnya Undang-U ndang Perlindungan Saksi dan Korban Nomor 13 Tahun 2006 adalah suatu terobosan hukum yang menarik dalam hal akomodasi terhadap hak-hak saksi dan korban yang tidak diatur secara lengkap pada KUHAP (Kitab Undang-Undang Hukum Acara Pidana). Memang, UU ini belum komprehensif dan belum sempurna, namun sebagai produk hukum awal yang memberikan perlindungan terhadap hak-hak korban dan saksi, UU tersebut dapat dijadikan sebagai salah satu acuan utama.

Undang-Undang Perlindungan Saksi dan Korban secara tersurat menempatkan negara, melalui LPSK sebagai pihak utama yang memberikan 
perlindungan terhadap Saksi dan Korban. Pasal 1 angka (3) UU ini menyebutkan bahwa LPSK adalah lembaga yang bertugas dan berwenang untuk memberikan perlindungan dan hak-hak lain kepada Saksi/Korban sebagaimana diatur dalam UU itu. Kemudian pada pasal 12 UU yang sama disebutkan bahwa LPSK bertanggungjawab untuk menangani pemberian perlindungan dan bantuan kepada Saksi dan Korban berdasarkan tugas dan kewenangan sebagaimana diatur dalam UU.

Kewenangan yang besar dari LPSK ini menempatkan LPSK sebagai representasi dari negara dalam hal perlindungan saksi dan korban. Apalagi Pasal 13 UU Perlindungan Saksi dan Korban secara tersurat menyebutkan bahwa LPSK adalah bertanggungjawab terhadap Presiden dan membuat laporan secara berkala tentang pelaksanaan tugas LPSK kepada DPR paling sedikit sekali dalam 1 (satu) tahun (Siswanto Sunarso, 2012, 40).

Program pengajuan kebijakan publik yang pro hak-hak korban ini amat penting. Pada semua tingkat kelembagaan adalah amat penting untuk memiliki kebijakan tertulis dan hukum yang mengatur bagaimana seharusnya korban diperlakukan. Kebijakan ini harus terintegrasi antara hukum pidana, hukum perdata dan hukum administratif. Kebijakan ini juga bisa dalam bentuk memperbaharui atau merevisi UU yang sudah ada namun dirasakan sudah tidak relevan lagi. Inisiatif untuk mengajukan maupun mengkritisi kebijakan yang melindungi hak-hak korban bisa datang baik dari negara maupun dari masyarakat.

\section{Permasalahan dalam Pemenuhan Hak dan Perlindungan Korban Tindak Pidana Ditinjau dari Faktor Peraturan Perundang-Undangan}

Banyak wilayah hukum yang belum diatur oleh undang-undang yang spesifik, ataupun UU ada namun masih bersifat parsial dan keberadaannya tersebar dalam berbagai peraturan perundang- undangan sehingga hanya berlaku bagi kejahatankejahatan tertentu. Ada pula UU yang belum memiliki peraturan pelaksana sehingga belum dapat dijalankan secara optimal. Setiap peraturan perundang-undangan dapat dikatakan baik (good legislation), sah menurut hukum (legal validity) dan berlaku efektif karena dapat diterima masyarakat secara wajar dan berlaku untuk waktu yang panjang, sehingga harus didasarkan pada landasan peraturan perundang-undangan.

Berikut beberapa pasal dalam peraturan perundang-undangan yang perlu untuk ditinjau ulang karena normanya yang kurang jelas mengatur:

\section{A. Undang-Undang Nomor 31 Tahun 2014 Tentang Perubahan Atas Undang-Undang Nomor 13 Tahun 2006 Tentang Perlindungan Saksi dan Korban}

1. Pasal 7A

(1) Korban tindak pidana berhak memperoleh Restitusi berupa; a) ganti kerugian atas kehilangan kekayaan atau penghasilan, b) ganti kerugian yang ditimbulkan akibat penderitaan yang berkaitan langsung sebagai akibat tindak pidana; dan/atau, c) penggantian biaya perawatan medis dan/atau psikologis, (2) Tindak pidana sebagaimana dimaksud pada ayat (1) ditetapkan dengan Keputusan LPSK, (3) Pengajuan permohonan Restitusi dapat dilakukan sebelum atau setelah putusan pengadilan yang telah memperoleh kekuatan hukum tetap melalui LPSK, (4) Permohonan Restitusi diajukan sebelum putusan pengadilan yang telah memperoleh kekuatan hukum tetap, LPSK dapat mengajukan Restitusi kepada penuntut umum untuk dimuat dalam tuntutannya, (5) Permohonan Restitusi diajukan setelah putusan pengadilan yang telah memperoleh kekuatan hukum tetap, LPSK dapat mengajukan Restitusi kepada pengadilan untuk mendapat penetapan, (6) Korban tindak pidana meninggal dunia, Restitusi diberikan kepada Keluarga 
Korban yang merupakan ahli waris Korban. Pasal ini maupun aturan pelaksanaannya yakni Peraturan Pemerintah Republik Indonesia Nomor 44 Tahun 2008 Tentang Pemberian Kompensasi, Restitusi, dan Bantuan Kepada Saksi dan Korban tidak dijelaskan ketentuan apabila terdakwa tidak dapat memberikan ganti kerugian karena tidak mampu, apakah bisa dilakukan pemaksaan agar dapatnya terdakwa melaksanakan penetapan restitusi atau negara yang akan mengambil alih jika memang terdakwa tidak mampu memenuhi kewajiban untuk memberikan restitusi. Ketidak jelasan ini nantinya juga akan menimbulkan masalah dalam penerapannya, karena dimungkinkan pula ada sebuah kasus dimana pelaku tindak pidana ini berasal dari kalangan yang tidak mampu sehingga tidak bisa memberikan ganti kerugian kepada korbannya.

2. Pasal 29

Tata cara memperoleh perlindungan sebagaimana dimaksud dalam Pasal 5 sebagai berikut; a) Saksi dan/atau Korban yang bersangkutan, baik atas inisiatif sendiri maupun atas permintaan pejabat yang berwenang, mengajukan permohonan secara tertulis kepada LPSK, b) LPSK segera melakukan pemeriksaan terhadap permohonan sebagaimana dimaksud pada huruf (a), c) Keputusan LPSK diberikan secara tertulis paling lambat 7 (tujuh) hari sejak permohonan perlindungan diajukan.

Undang-undang tentang kekerasan dalam rumah tangga dijelaskan tentang perlindungan sementara yang harus langsung dilakukan setelah ada laporan di kepolisian, namun di UU LPSK tidak disebutkan adanya perlindungan sementara sehingga untuk korban tindak pidana selain KDRT harus menunggu dengan proses yang lama yakni untuk keputusan pemberian perlindungan saja harus menunggu paling lambat 7 hari. Respon yang lambat ini tentunya akan membahayakan seorang korban tindak pidana jika ia mendapat ancaman yang tidak bisa diprediksi waktu dilakukannya ancaman tersebut oleh pelaku.

Tersebarnya aturan tentang korban tindak pidana dalam beberapa peraturan perundangan ini tentunya perlu untuk diseragamkan menjadi suatu konsep utuh tentang perlindungan korban. Perlu adanya batasan-batasan yang jelas dan skema yang jelas tentang aturan perlindungan korban tindak pidana.

Sebagaimana Jeremy Bentham berpendapat bahwa; "Tanpa hukum, tidak ada rasa aman, dan tanpa rasa aman nilai-nilai kelangsungan hidup, kemakmuran dan kesetaraan tidak akan dapat tercapai melalui hukum. Rasa aman itu sendiri tercapai karena terpeliharanya ekspektasi. Ekspektasi adalah firasat yang memberi kita kekuatan untuk membentuk suatu rencana perilaku umum yang menjamin bahwa rangkaian momen yang membentuk kehidupan bukan titik-titik yang saling terpisah dan independen, melainkan menjadi bagian-bagian dari suatu keseluruhan yang saling berhubungan".

Renungan pemikiran bentham ini menjelaskan bahwa pengharapan ke depan (expectation) mengenai hukum tidak boleh dipandang secara parsial berdasarkan kebutuhan-kebutuhan sesaat terhadap elemen-elemen hukum. Hukum harus dilihat sebagai suatu kesatuan yang integral, karena hukum adalah suatu sistem, yang bagian-bagiannya atau komponen-komponennya adalah keseluruhan yang saling berkolerasi (Jeremy Bentham, 2006, 15-16).

Asas-asas pembentukan peraturan perundangundangan yang baik (good legislation principles) telah dijelaskan beberapa hal yang meliputi;

a) Asas kejelasan tujuan adalah bahwa setiap pembentukan peraturan perundangundangan harus mempunyai tujuan yang jelas yang hendak dicapai; 
b) Kelembagaan atau organ pembentuk yang tepat adalah bahwa setiap jenis peraturan perundang-undangan harus dibuat oleh lembaga/pejabat pembentuk peraturan perundang-undangan yang berwenang. Peraturan perundang-undangan tersebut dapat dibatalkan atau batal demi hukum, bila dibuat oleh lembaga/pejabat yang tidak berwenang;

c) Asas kesamaan jenis dan materi muatan, adalah bahwa dalam pembentukan peraturan perundang-undangan harus benarbenar memperhatikan materi muatan yang tepat dengan jenis peraturan perundangundangannya;

d) Asas dapat dilaksanakan, adalah bahwa pembentukan peraturan perundangundangan harus memperhatikan efektivitas peraturan perundang-undangan tersebut di dalam masyarakat, baik secara filosofis, yuridis, maupun sosiologis;

e) Asas kedayagunaan dan kehasilgunaan, adalah bahwa peraturan perundangundangan dibuat karena memang benarbenar dibutuhkan dan bermanfaat dalam mengatur kehidupan bermasyarakat, berbangsa dan bernegara;

f) Asas kejelasan rumusan, adalah bahwa setiap peraturan perundang-undangan harus memenuhi persyaratan teknis penyusunan peraturan perundang-undangan, sistematika dan pilihan kata atau terminologi, serta bahasa hukumnya jelas dan mudah dimengerti, sehingga tidak menimbulkan berbagai macam interpretasi dalam pelaksanaannya;

g) Asas keterbukaan adalah bahwa dalam proses pembentukan peraturan perundang-undangan mulai dari perencanaan, persiapan, penyusunan, dan pembahasan besifat transparan dan terbuka. Dengan demikian, seluruh lapisan masyarakat mempunyai kesempatan yang seluas-luas- nya untuk memberikan masukan dalam proses pembuatan peraturan perundangundangan.

Beberapa asas tersebut terdapat asas diterapkan secara sebagian dalam peraturan perundang-undangan diatas, yakni asas kejelasan rumusan. Disini kejelasan rumusan tidak hanya diartikan jelas bahasa hukumnya, namun juga juga jelas dalam pelaksanaannya. Terjadi kesulitan dalam penerapan suatu pasal jika rumusan yang terdapat dalam pasal tersebut tidak terdapat penjelasan lebih lanjut melalui aturan pelaksananya, sehingga dalam praktik para penegak hukum yang sudah terbentuk dengan budaya hukum tertulis akan sangat kesulitan dalam melaksanakan aturan dalam pasal tersebut.

Seharusnya dari pasal-pasal dalam peraturan perundang-undangan diatas di buatkan sebuah Peraturan Pemerintah untuk melaksanakannya. Materi muatan peraturan pemerintah, peraturan pemerintah adalah peraturan yang dibentuk sebagai peraturan yang menjalankan UU. Peraturan Pemerintah (PP) dibentuk agar ketentuan dalam UU dapat berjalan. Menurut bagir manan, yang diartikan dengan melaksanakan undang-undang, bahwa PP hanya berisi ketentuan lebih lanjut (rincian) dari ketentuan-ketentuan yang telah terdapat dalam UU. Dengan perkataan lain setiap ketentuan dalam PP harus berkaitan satu atau beberapa ketentuan UU.

Hal ini tentunya telah dikemukakan oleh H.L.A. Hart bahwa hukum secara ide tidak dapat dipungkiri dan tidak dapat melarikan diri dari kenyataan bahwa ia memiliki "open texture". Hal ini berarti bahwa tidak peduli seberapa hati-hati aturan-aturan dirumuskan, akan tetap ada dalam level-level tertentu sebuah ketidakpastian yang menghantui dan mengelilingi makna serta penerapannya (H.L.A. Hart, 1994, 135). 


\section{B. Undang-Undang Nomor 23 Tahun 2004 Tentang Penghapusan Kekerasan dalam Rumah Tangga}

Pasal 16 (1) disebutkan; "Dalam waktu $1 x$ 24 (satu kali dua puluh empat jam) terhitung sejak mengetahui atau menerima laporan kekerasan dalam rumah tangga, kepolisian wajib segera memberikan perlindungan sementara pada korban." Pasal ini disebutkan tentang kewajiban kepolisian dalam memberikan perlindungan sementara pada korban kekerasan dalam rumah tangga namun tidak ada penjelasan lebih lanjut tentang bagaimana perlindungan sementara ini dilakukan.

Ketidakjelasan ini tentu saja mempunyai akibat buruk, Contohlah sebuah kasus pembunuhan sadis yang terjadi di Kabupaten Malang, Pada tanggal 4 Agustus 2015 di Kecamatan Jabung, Kabupaten Malang, seorang bapak Abdullah (50) tega menghabisi nyawa Wiwik Halimah (48), istri dan Putri Sari Devi (16) anaknya. Abdullah membunuh kedua korban dengan menggorokkan sebilah parang keleher masing-masing korban. Sebelumnya telah sering terjadi pertengkaran antara keduanya bahkan pada tanggal 2 Agustus 2015, 2 hari sebelum peristiwa pembunuhan korban melaporkan suaminya ke Kepolisian sektor Jabung atas kekerasan yang dilakukan oleh suaminya, namun oleh kepolisian laporan tersebut dikembalikan untuk diselesaikan di kelurahan. Tanggal 4 Agustus 2015 telah dijadwalkan pertemuan oleh kelurahan untuk memediasi suami istri tersebut. Namun ternyata 2 hari kemudian terjadilah peristiwa pembunuhan sadis tersebut yang seharusnya dapat dicegah oleh peran kepolisian pada saat korban melapor (Eko Widianto, www.tempo.com, 2017).

Kejadian di atas ada beberapa hal yang perlu diperhatikan, jika ditarik ke belakang aparat kepolisian yang seharusnya memberi tindakan tegas berupa perlindungan sementara sebagai amanat undang-undang telah gagal melindungi seorang korban tindak pidana dengan mengembalikan laporan tersebut agar diselesaikan melalui jalur kekeluargaan lewat kelurahan. Padahal dalam undang-undang telah jelas disebut kepolisian wajib memberikan perlindungan sementara pada korban tindak pidana kekerasan dalam rumah tangga.

Namun jika melihat dari pasal tersebut, Ketidak jelasan pasal yang ada membuat aparat mungkin menjadi ragu untuk menerapkan ketentuan pasal tersebut. Karena dalam aturan pelaksanaan Undang-undang ini tidak dijelaskan lebih lanjut tentang perlindungan sementara yang harus diberikan. Aparat kepolisian mungkin secara prosedural merasa kesulitan untuk menerapkan aturan dalam pasal ini karena tidak terdapat aturan pelaksana yang secara teknis dapat mengakomodir maksud pasal ini. Maksud perlindungan sementara tidak dijelaskan sehingga dalam praktek aparat mengalami kesulitan dalam pelaksanaan perlindungan sementara ini.

Salah satu tulisan Klatt, menggulirkan problematika yuridis, yakni tidak dapat ditentukan apa hukumnya secara tepat (legal indeterminacy). Legal indeterminacy ini kemungkinan disebabkan oleh berbagai hal, antara lain; kekaburan makna (vagueness), kemendua artian makna (ambiguity), inkonsistensi (inconsistency). Kekaburan makna norma atau bisa di sebut Vagueness memiliki tiga kategori menurut Walter Jellinek, Koch and Rubmann dalam buku Mathias Klatt, "There are three categories of vagueness; 1) There are indviduals to which the concept undoubtedly applies (so-called positive candidates), 2) There are individuals to which the concept does undoubtedly not apply (so-called negative candidates), 3) There are individuals as to which it is debateable whether the concept apllies or not (so-called neutral candidates)." (Walter Jellinek, Koch dan Rubman, 2008, 48).

Kategori di atas maka bunyi "perlindungan sementara" dalam pasal di atas masuk dalam kategori ketiga yakni "ada individu yang padanya ini diperdebatkan apakah konsep itu berlaku atau tidak". Karena memang peraturan pelaksanaan tidak menjelaskan bagaimana perlindungan se- 
mentara itu diberikan, apakah dengan menyuruh si pelapor sementara tinggal di kepolisian, kalaupun tinggal di kantor kepolisian setempat yang mana hal tersebut tidak memungkinkan mengingat tidak adanya fasilitas untuk menginap, kemudian apakah pelapor sementara dititipkan di dinas sosial misalnya, atau mungkinkah anggota kepolisisan yang berjaga di rumah pelapor. Hal tersebut tidak dijelaskan lebih lanjut sehingga perlindungan sementara yang dimaksud pasal ini menjadi tidak jelas untuk dilaksanakan.

Jika kita melihat kebijakan di negara lain, Perlindungan terhadap korban dapat dilakukan dengan penguatan hukum. Sebagai contoh adalah Austria. Menangani kekerasan dalam rumah tangga (KDRT) atau domestic violence, Austria telah melakukan pergeseran dalam hukum yang menanganinya. Semula masalah KDRT dianggap masalah pribadi namun kemudian dianggap menjadi masalah negara dan bagian dari kepentingan publik.

Melalui undang-undang tentang perlindungan terhadap kekerasan dalam keluarga yang berlaku sejak 1 Mei 1997, Austria menerapkan semacam peribahasa seperti; "siapa saja yang memukul harus meninggalkan rumah dan bertanggungjawab terhadap tindakannya" (whoever beats will have to leave and take responsibility of their action). Melalui pengaturan ini, pihak yang melakukan kekerasan-lah yang harus meninggalkan rumah dan bukannya korban kekerasannya.

Perhatian yang sama terhadap korban KDRT ditunjukkan oleh Pemerintah Jerman. Tahun 2002 Pemerintah Jerman menelurkan hukum yang meningkatkan perlindungan melalui hukum perdata dalam kasus KDRT dan memfasilitasi perpindahan tempat tinggal setelah terjadi perpisahan akibat KDRT tersebut. Berdasarkan legislasi ini, polisi berhak untuk melindungi seseorang dari bahaya tertentu dan dapat memindahkan pasangannya yang melakukan kekerasan dengan mengeluarkan surat perintah penahanan berjangka waktu 7 sampai dengan 14 hari. Negara bagian Lower Saxony, surat perintah ini lebih singkat lagi, antara 7 sampai dengan 10 hari.

Melalui surat perintah penahanan ini bertujuan untuk sesegera mungkin mengakhiri kekerasan. Sang pelaku kekerasan harus menyerahkan kunci rumah atau meninggalkan tempat tinggal tersebut, mengemas barang-barang pribadinya dan segera meninggalkan rumah. Maksud dari kebijakan ini adalah untuk menghindari kekerasan yang mungkin akan terjadi lagi pada korban KDRT dengan memberikan mereka cukup waktu untuk beristirahat dan memulihkan diri di dalam rumah mereka sendiri atau lingkungan yang mereka akrabi, guna kepentingan pemulihan dan menghadapi masa depannya (Ute I. Haas, 2009).

Gagasan dari negara-negara di atas mungkin dapat dipakai sebagai pertimbangan nantinya dalam merumuskan perlindungan yang tepat kepada seseorang yang melapor sebagai korban kekerasan dalam rumah tangga.

\section{Penutup}

Bahwa sistem pemidanaan yang berlaku saat ini di Indonesia lebih menggunakan pendekatan penyelesaian perkara pidana dengan cara penghukuman (pemidanaan) atau dikenal dengan istilah retributive justice. Semua bentuk kejahatan yang terbukti di persidangan diputus dengan cara menghukum pelaku, sedangkan hak-hak korban kejahatan seperti kurang diperhatikan.

Korban utama atas terjadinya suatu tindak pidana bukanlah negara, sebagaimana dalam sistem peradilan pidana yang ada sekarang. Jadi hak-hak korban seharusnya tetap diutamakan, yakni hak-haknya yang terampas akibat perbuatan pidana tersebut.

Beberapa peraturan perundang-undangan yang mengatur tentang korban tindak pidana perlu adanya pembaharuan lagi agar hak-hak korban terpenuhi dan terlindungi sesuai konsep restorative justice, yakni dalam Undang-undang Nomor 23 
Tahun 2004 tentang Penghapusan Kekerasan dalam Rumah Tangga, Undang-undang Nomor 31 Tahun 2014 Tentang Perubahan Atas Undang-undang Nomor 13 Tahun 2006 Tentang Perlindungan Saksi dan Korban.

\section{DAFTAR PUSTAKA}

\section{Buku}

Bentham, Jeremy, 2006, Teori Perundang-Undangan, Prinsip-prinsip Legislasi, Hukum Perdata dan Hukum Pidana, diterjemahkan Nurhadi, MA, Nusamedia \& Nuansa, Bandung.

Hart, H.L.A., 1994, The Concept of Law, Oxford University Press, Oxford.

Subakti, Natangsa, 2014, Peradilan Restorative dalam Bingkai Empiris, Teori, dan Kebijakan, Genta Publishing, Yogyakarta.

Sunarso, Siswanto, 2012, Viktimologi dalam Sistem Peradilan Pidana, Sinar Grafika, Jakarta.

\section{Artikel dari Jurnal Ilmiah}

Haas, Ute I., Assistance for Victims of Domestic Violence dalam OtmarHagemann, et.al, 2009, Victimology,
Victim Assistance and Criminal Justice, Perspectives Shared by International Experts at the Inter-University Centre of Dubrovnik, Monchengladbach, Niederrhein University of Applied Sciences Department of Social Work and Cultural Studies.

Klatt, Mathias, 2008, Making the Law explicit: The normativity of Legal Argumentation, Oxford and Portland Oregon, Hart Publisihing.

\section{Artikel Ilmiah dari Internet}

Widianto, Eko, Lihat Polisi, Pria Pembunuh Istri dan Anak Ini Sesak Napas, www.tempo.com, diakses pada tanggal 5 Januari 2017 pukul 20.00 wib.

Semendawai, Abdul Haris, Pentingnya Pemulihan Hak Korban dalam Sistem Peradilan Pidana, www.obsessionnews.com, diakses pada tanggal 1 Maret 2017 pukul 10.00 Wib.

Karya Tidak Dipublikasikan

Mudzakir, 2010, Posisi Hukum Korban Kejahatan Dalam Sistem Peradilan Pidana, Disertasi, Program Pascasarjana FH-UI, Jakarta. 